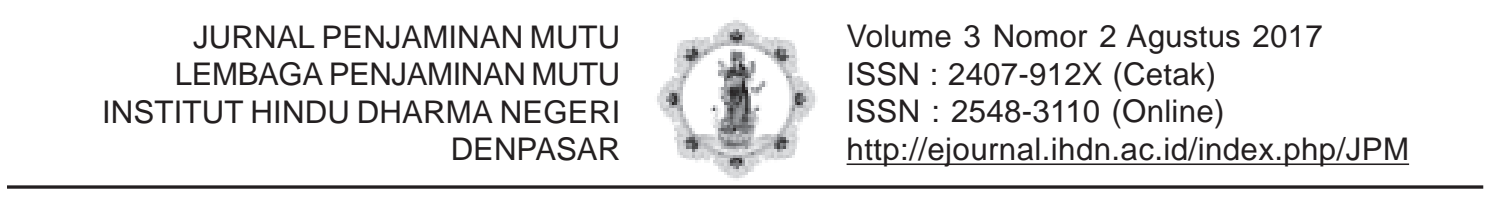

\title{
TUMPEK UDUH, KEARIFAN LOKAL BALI UNTUK MENINGKATKAN MUTU PENDIDIKAN KARAKTER
}

\author{
Oleh \\ I Nyoman Payuyasa \\ Institut Seni Indonesia Denpasar \\ guz payu@yahoo.com
}

Diterima 29 Juni 2017, direvisi 07 Agustus 2017, diterbitkan 31 Agustus 2017

\begin{abstract}
Local wisdom is the values that will be strongly attached to society because of this value through a long travel time, as long as the existence of that society. Local wisdom is a way of life for the people. Trust and respect for the meaning of local wisdom is a seriousness. One of them tumpek uduh / pengatag, as the media is also a reminder that people can understand that character education should be given early on. Seeing the culture of society that is very respectful of local wisdom values, then this local wisdom is a facility and a bridge both to realize the value of character education in learners and the wider community. Synchronization between local wisdom and character education values is required. So that the quality of character education is good with the media of local wisdom.
\end{abstract}

Keywords: Local wisdom, character education, Tumpek Uduh

\section{PENDAHULUAN}

Kehidupan manusia dikelilingi oleh budaya, hal ini disebabkan karena manusia selalu berupaya mempertahankan eksistensinya dalam kehidupan yang mengharuskannya selalu bersinggungan dengan lingkungan sekitar, baik lingkungan fisik dan nonfisik. Proses pembentukan budaya berlangsung berabadabad dan teruji sehingga membentuk suatu komponen yang handal, terbukti dan diyakini dapat membawa kesejahteraan lahir dan batin. Komponen inilah yang disebut dengan jati diri.
Di dalam jati diri terkandung kearifan lokal (local wisdom) yang merupakan hasil dari Local Genius dari berbagai suku bangsa, kearifan lokal inilah seharusnya dirajut dalam satu kesatuan kebudayaan (Culture) untuk mewujudkan suatu bangsa yaitu, Bangsa Indonesia. Budaya dilahirkan beribu tahun yang lalu sejak manusia ada di Bumi. Kebiasaan yang bagai telah menjadi dan membentuk perilaku manusia tersebut diwariskan dari generasi ke generasi selanjutnya. Budaya itu sendiri merupakan suatu produk dari akal budi manusia, setidaknya apabila dilakukan 
pendekatan secara etimologi. Budaya dalam hal ini disebut kebudayaan sangat erat kaitannya dengan masyarakat.

Agar eksistensi budaya tetap kukuh, maka kepada generasi penerus dan pelurus perjuangan bangsa perlu ditanamkan rasa cinta akankebudayaanlokal khususnya di daerah. Salah satu cara yang dapat ditempuhdi sekolah adalah dengan cara mengintegrasikan nilai-nilai kearifan budaya lokal dalam proses pembelajaran, ekstra kurikuler, atau kegiatan kesiswaan di sekolah. Misalnya dengan mengaplikasikan secara optimal Pendidikan Karakter Berbasis Kearifan Budaya Lokal.

Menurut T. Ramli (2003), pendidikan karakter memiliki esensi dan makna yang sama dengan pendidikan moral dan pendidikan akhlak. Tujuannya adalah membentuk pribadi anak, supaya menjadi manusia yang baik, warga masyarakat, dan warga negara yang baik. Adapun kriteria manusia yang baik, warga masyarakat yang baik, dan warga negara yang baik bagi suatu masyarakat atau bangsa, secara umum adalah nilai-nilai sosial tertentu, yang banyak dipengaruhi oleh budaya masyarakat dan bangsanya. Oleh karena itu, hakikat dari pendidikan karakter dalam konteks pendidikan di Indonesia adalah pedidikan nilai, yakni pendidikan nilai-nilai luhuryang bersumber dari budaya bangsa Indonesia sendiri, dalam rangka membina kepribadian generasi muda.

Pembangunan karakter dan jati diri bangsa merupakan cita-cita luhur yang harus diwujudkan melalui penyelenggaraan pendidikan yang terarah dan berkelanjutan. Penanaman nilai-nilai akhlak, moral, dan budi pekerti seperti tertuang dalam Undang- undang Republik Indonesia Nomor 20 Tahun 2003 tentang Sistem Pendidikan Nasional harus menjadi dasar pijakan utama dalam mendesain, melaksanakan, dan mengevaluasi sistem pendidikan nasional. Tujuan pendidikan nasional jelas telah melahirkan dasar-dasar yang kuat dalam menopang pembangunan karakter dan jati diri bangsa. Namun, penyelenggaraan pendidikan telah mengalami degradasi yang sangat mengkhawatirkan, di mana nilai-nilai kearifan lokal telah terbungkus oleh kuatnya arus pendidikan global, kecerdasan pribadi intelektual menjadi ukuran yang lebih dominan untuk menentukan keberhasilan dalam menempuh pendidikan. Upaya penyeragaman kemampuan telahmembelenggu tumbuh dan berkembangnya keragaman kemampuan sebagai pencerminan beragamnya kekayaan budaya bangsa. Akibatnya, menipisnya tatakrama, etika, dan kreatifitas anak bangsa menjadi fenomena yang perlu mendapat perhatian serius dalam menata pendidikan di masa yang akan datang. Oleh karena itu, pendidikan karakter bangsa dipandang sebagai solusi cerdas untuk menghasilkan peserta didik yang memiliki kepribadian unggul, berakhlak mulia, dan menjunjung tinggi nilai-nilai keindonesian secara menyeluruh.Untuk itulah penting kiranya menanamkan kembali kearifan lokal di setiap daerah untuk membantu pemahaman dan peningkatan mutu pendidikan karakter. Penelitian ini bertujuan untuk mendeskripsikan filosofi tumpek uduh/ pengatag sebagai salah satu kearifan lokal Bali untuk membantu peningkatan mutu pendididkan karakter.

\section{PEMBAHASAN}

Pelaksanaan pendidikan karakter dalam proses pembelajaran selama ini nampaknya belum menghasilkan sesuatu yang memuaskan. Ini terlihat dari berbagai macam permasalahan yang muncul ke permukaan. Namun bukan berarti pencanangan pendidikan karakter dalam ruang belajar itu gagal. Perlu dilakukan terobosan-terobosan penyegaran untuk meningkatkan hasil atau mutu pendidikan karakterini.

Melibatkan dan menggunakan kearifan lokal sebagai anak panah penembus sasaran yang tepat perlu digiatkan. Pendidikan karakter perlu dukungan dari yang sifatnya telah mendapat tempat di masyarakat. Kearifan lokal 
selama ini merupakan salah satu pedoman hidup bermasyarakat di Indonesia. Banyak nilai yang bisa diklaborasikan untuk meningkatkan kualitas dan mutu pendidikan karakter yang ampuh.

Istilah karakter merujuk pada ciri khas, perilaku khas seseorang atau kelompok, kekuatan moral, atau reputasi. Dengan demikian, karakter adalah evaluasi terhadap kualitas moral individu atau berbagai atribut termasuk keberadaan kurangnya kebajikan seperti integritas, keberanian, ketabahan, kejujuran dan kesetiaan, atau kebiasaan yang baik. Ketika seseorang memiliki karakter moral, hal inilah yang membedakan kualitas individu yang satu dibandingkan dari yang lain (Koesoema, 2007:32). Karakter juga dipahami sebagai seperangkat ciri perilaku yang melekat pada diriseseorang yang menggambarkan tentang keberadaan dirinya kepada orang lain.

Pendidikan karakter pada intinya bertujuan membentuk bangsa yang tangguh,kompetitif, berakhlak mulia, bermoral, bertoleran, bergotong royong, berjiwa patriotik, berkembang dinamis, berorientasi ilmu pengetahuan dan teknologi yang semuanya dijiwaioleh iman dan takwa kepada Tuhan yang Maha Esa berdasarkan Pancasila. Pendidikan karakter berfungsi (1) mengembangkan potensi dasar agar berhati baik, berpikiran baik, dan berperilaku baik; (2) memperkuat dan membangun perilaku bangsa yangmultikultur; (3) meningkatkan peradaban bangsa yang kompetitif dalam pergaulan dunia.Pendidikan karakter dilakukan melalui berbagai media yang mencakup keluarga,satuan pendidikan, masyarakat sipil, masyarakat politik, pemerintah, dunia usaha, dan mediamassa.

Pelaksanaan pendidikan karakter dalam pembelajaran adalah pendidikan budi pekerti plus, yaitu yang melibatkan aspek pengetahuan (cognitive), perasaan (feeling), dan tindakan (action). Menurut Thomas Lickona (dalam Koesoema, 2007:65), tanpa ketiga aspek ini, maka pendidikan karakter tidak akan efektif, dan pelaksanaannya pun harus dilakukan secara sistematis dan berkelanjutan. Dengan pendidikan karakter, seorang anak akan menjadi cerdas emosinya. Kecerdasan emosi adalah bekal terpenting dalam mempersiapkan anak menyongsong masa depan, karena dengannya seseorang akan dapat berhasil dalam menghadapi segala macam tantangan, termasuk tantangan untuk berhasil secara akademis. Sebuah penelitian menyatakan bahwa ada sederet faktor-faktor risiko penyebab kegagalan anak di sekolah. Faktorfaktor risiko yang disebutkan ternyata bukan terletak pada kecerdasan otak, tetapi pada karakter, yaitu rasa percaya diri, kemampuan bekerja sama, kemampuan bergaul, kemampuan berkonsentrasi, rasa empati, dan kemampuan berkomunikasi.

Dalam penilaian hasil belajar, semua guru akan dan seharusnya mengukur kemampuan siswa dalam semua ranah (Kemendiknas, 2011). Dengan penilaian seperti itu maka akan tergambar sosok utuh siswa sebenarnya. Artinya, dalam menentukan keberhasilan siswa harus dinilai dari berbagai ranah seperti pengetahuan (kognitif), sikap (afektif), dan perilaku (psikomotor). Seorang siswa yang menempuh ulangan bahasa Indonesia secara tertulis, sebenarnya siswa tersebut dinilai kemampuan penalarannya yaitu kemampuan mengerjakan soal-soal yang juga dinilai kemampuan pendidikan karakter bangsanya yaitu kemampuan melakukan kejujuran dengan tidak menyontek dan bertanya kepada teman dan hal ini disikapi karena perbuatan-perbuatan tersebut tidak baik. Di samping itu, ia dinilai kemampuan gerak-geriknya, yaitu kemampuan mengerjakan soal-soal ujian dengan tulisan yang teratur, rapi, dan mudah dibaca (Kemendiknas, 2011).

Pelaksanaan pendidikan karakter teridentifikasi menjadi delapan belas nilai yang bersumber dari agama, Pancasila, budaya, dan tujuan pendidikan nasional, yaitu: (1) Religius, (2) Jujur, (3) Toleransi, (4) Disiplin, (5) Kerja 
keras, (6) Kreatif, (7) Mandiri, (8) Demokratis, (9) Rasa Ingin Tahu, (10) Semangat Kebangsaan, (11) Cinta Tanah Air, (12) Menghargai Prestasi, (13) Bersahabat/ Komunikatif, (14) Cinta Damai, Sopan santun (15) Gemar Membaca, (16) Peduli Lingkungan, (17) Peduli Sosial, \& (18) Tanggung Jawab (Pusat Kurikulum. Pengembangan dan Pendidikan Budaya \& Karakter Bangsa: Pedoman Sekolah. 2009:10). Delapan belas nilai pembentuk karakter bangsa, bukan harga mati sebab satuanpendidikan dapat menentukan prioritas pengembangannya dengan cara melanjutkan nilaiprakondisi yang diperkuat dengan beberapa nilai yang diprioritaskan dari delapan belas nilai di atas.

Pengimplementasian jumlah dan jenis karakter yang dipilih tentu akan dapat berbedaantara satu daerah atau sekolah yang satu dengan yang lain. Hal itu bergantung padakepentingan dan kondisi satuan pendidikan masing-masing. Di antara berbagai nilai yangdikembangkan, dalam pelaksanaannya dapat dimulai dari nilai yang esensial, sederhana, danmudah dilaksanakan sesuai dengan kondisi masing-masing sekolah.

1. Kereligiusan : pikiran, perkataan, dan tindakan seseorang yang diupayakan selalu berdasarkan pada nilai-nilai Ketuhanan dan/atau ajaran agamanya.

2. Kejujuran : perilaku yang didasarkan pada upaya menjadikan dirinya sebagai orang yang selalu dapat dipercaya dalam perkataan, tindakan, dan pekerjaan, baik terhadap diri dan pihak lain.

3. Kecerdasan: kemampuan seseorang dalam melakukan suatu tugas secara cermat, tepat, dan cepat.

4. Tanggung jawab : sikap dan perilaku seseorang untuk melaksanakan tugas dan kewajibannya sebagaimana yang seharusnya dia lakukan, terhadap diri sendiri, masyarakat, lingkungan (alam, sosial, dan budaya), negara dan Tuhan
Yang Maha Esa.

5. Kebersihan dan kesehatan :segala upaya untuk menerapkan kebiasaan yang baik dalam menciptakan hidup yang bersih dan sehat dan menghindarkan kebiasaan buruk yang dapat mengganggu kesehatan.

6. Kedisiplinan : tindakan yang menunjukkan perilaku tertib dan patuh pada berbagai ketentuan dan peraturan.

7. Tolong-menolong :sikap dan tindakan yang selalu berupaya menolong orang.

8. Berpikir logis, kritis, kreatif, dan inovatif : berpikir dan melakukan sesuatu berdasarkan kenyataan dan/ atau nalar untuk menghasilkan cara dan/atau produk baru atau termutakhir.

9. Kesantunan : sifat yang halus dan baik dari sudut pandang tata bahasa maupun tata perilakunya ke semua orang.

10. Ketangguhan : sikap dan perilaku pantang menyerah atau tidak pernah putus asa ketika menghadapi berbagai kesulitan dalam melaksanakan kegiatan atau tugas sehingga mampu mengatasi kesulitan tersebut dalam mencapai tujuan.

11. Kedemokratisan : cara berfikir, bersikap, dan bertindak yang menilai sama hak dan kewajiban dirinya dan orang lain.

12. Kemandirian : sikap dan perilaku yang tidak mudah tergantung pada orang lain dalam menyelesaikan tugas-tugas.

\subsection{Tumpek Uduh/Pengatag sebagai jembatan Pendidikan Karakter}

"Naiklah ke pungguh Ayah, nak dan katakan pada pohon pisang ini untuk tumbuh subur agar kelak dapat memberimu buah-buah bergizi juga pemikiran yang sehat" Kalimat ini diucapkan seorang ayah kepada putranya saat melakukan ritual tumpek 
uduh atau tumpek wariga di Karangasem, Bali. Sang ayah sengaja mengajak anak satu-satunya ini turut serta dalam rangkaian tradisi yang dipercaya sebagai ungkapan rasa terima kasih kepada seluruh pepohonan dan tanaman yang telah memberi hidup bagi manusia, agar anaknya dapat mengerti arti penting memelihara lingkungan sekitar.

"Nini Nini, buin selae dina galungan. Mabuah apang nged... nged... nged." Inilah kalimat-kalimat yang diujarkan sang ayah sembari mengetokkan golok di tangan kanan pada pohon jambu yang berbunga.Dia memberi sedikit luka pada batang itu. Hal sama juga dilakukan pada pohon cempaka, belimbing, srikaya, kenanga, dan sejumlah tanaman lain di pekarangan itu pada perayaan tumpek wariga

"Nenek nenek, 25 hari lagi Galungan. Berbuahlah agar lebat... lebat... lebat...," begitu makna kalimat berbahasa Bali yang selalu diucapkan pada perayaan ini.

Hari itu, ungkapan syukur kepada Tuhan atas kesuburan tanaman hingga tumbuh baik dan menghasilkan buah atau bunga lebat.

Tumpek wariga, juga disebut tumpek bubuh, tumpek uduh, tumpek pengatag, dirayakan umat Hindu setiap 210 hari sekali, atau 25 hari sebelum Hari Raya Galungan. Sebagai ucap syukur, umat Hindu mempersembahkan sesaji buah dan bunga, serta bubur sumsum (terbuat dari tepung beras, ditaburi kelapa dan gula merah cair). Tumpek wariga ini merupakan kearifan lokal dari para leluhur agar warga selalu menjaga lingkungan dengan selalu menanam pohon di pekarangan.

Upacara tumpek bubuh atau tumpek wariga pada masyarakat Bali, yang dilaksanakan pada hari Saniscara Kliwon Wariga setiap 210 hari sekali, dapat ditanggapi sebagai usaha untuk melestarikan lingkungan. Upacara ini adalah dalam rangka pemujaan Tuhan dalam manifestasinya sebagai Dewa Sangkara sebagai dewanya tumbuhtumbuhan.Tujuan umat Hindu menghaturkan upacara pada hari ini adalah untuk menghaturkan rasa terima kasih kehadapan Ida Sang Hyang Widhi Wasa dalam manifestasi sebagai Bhatara Sangkara, bahwa beliau telah menciptakan tumbuh-tumbuhan serta memohon agar tumbuh-tumbuhan itu dapat berkembang biak dengan baik dan berguna bagi manusia. Sekaligus juga memohon agar tumbuhtumbuhan berbuah baik dan banyak sehingga ketika menjelang Galungan agar dapat dipergunakan sebagai sarana upacara persembahan di hari raya Galungan. Pada umumnya, upacara ini dilakukan di pekarangan/ perkebunan, tegalan yang banyak dipelihara pepohonan yang berguna bagi kehidupan manusia. Perayaan hari tumpek pengatag, tumpek bubuh, tumpek wariga, dan apapun sebutannya, mengajarkan pada umat manusia bahwa kita wajib bersyukur atas harmoni yang membantu kita tinggal dalam alam kehidupan kini. Menghormati dan menghargai bumi dan seisinya, khususnya tanaman yang ada, memberi isyarat dan makna mendalam agar manusia mengasihi dan menyayangi alam dan lingkungan yang telah berjasa menopang hidup dan penghidupannya.

Pada tumpek pengatag, momentum kasih dan sayang kepada alam itu diarahkan kepada tumbuh-tumbuhan. Betapa besarnya peranan tumbuh-tumbuhan dalam memberi hidup umat manusia. Hampir seluruh kebutuhan hidup umat manusia bersumber dari tumbuh-tumbuhan. Mulai dari pangan, sandang hingga papan. Karena itu pula, tradisi perayaan tumpek pengatag tidaklah keliru jika disepadankan sebagai peringatan Hari Bumi gaya Bali dan kini bisa direaktualisasi sebagai hari untuk menanam pohon.Tumpek pengatag merupakan momentum untuk memahami dan bersyukur atas segala jasa Ibu Pertiwi kepada umat manusia. Bersahabat dengan alam, tidak merusak lingkungan, belajar dari pengalaman para leluhur atau para tetua Bali di masa lalu, yang telah memiliki visi futuristik untuk menjaga agar Bali tak meradang menjadi tanah gersang dan kerontang akibat alam lingkungan yang tak 
terjaga.Kesadaran yang tumbuh dalam pengertian makrokosmik, dalam konteks semesta raya, tidak hanya semata Bali. Visi dan misi dari segala tradisi itu bukan semata menjaga kelestarian alam dan lingkungan Bali, tetapi juga kelestarian alam dan lingkungan seluruh dunia. Istimewanya, segala kearifan itu muncul jauh sebelum manusia di masa kini menggemakan upaya untuk menjaga kelestarian lingkungan.Jauh sebelum dunia menetapkan Hari Bumi, tradisi-tradisi Bali telah lebih dulu mewadahinya dengan arif. Bahkan jauh sebelum orang menetapkan Desember sebagai bulan menanam pohon, kegiatan ritual yang jatuh setiap 210 hari sekali itu, khusus dipersembahkan untuk tumbuh-tumbuhan yang selama ini telah mampu memberikan manfaat dan memudahkan bagi kehidupan umat manusia maupun aneka jenis satwa lainnya.Umat Hindu pada tumpek pengatag mempersembahkan rangkaian korban suci (upakara) yang salah satu komponennya adalah "bubuh sumsum", yakni bubur dari tepung ketan yang diberi warna hijau alami dari daun kayu sugih, ditaburi dengan parutan kelapa, dan diberi gula merah.

Kegiatan ritual tumpek pengatag dilakukan umat Hindu sejak pagi, siang, hingga sore terhadap semua jenis tanaman di sawah, ladang maupun pekarangan, sebagai salah satu bentuk menghargai aneka jenis tumbuh-tumbuhan yang selama ini mampu memberikan manfaat terhadap kehidupan umat manusia maupun aneka jenis satwa lainnya. Kearifan Lokal ini telah sejak dahulu dilakukan leluhur orang Bali dalam melestarikan lingkungan dengan mengajak seluruh anak-anaknya membuat lubang dan menanam pohon kelapa sambil menggendong anaknya satu per satu. Tradisi yang diwarisi hingga sekarang itu dipercaya membuat pohon kelapa yang ditanam itu kelak tumbuh subur, kuat, dan berbuah lebat.Kearifan lokal itu disertai dengan memberi contoh lewat perilaku menancapkan ranting muda di atas batang pohon yang baru ditebang. Pohon yang ditebang untuk keperluan membangun rumah atau bangunan fisik lainnya sengaja dipilih yang telah berumur belasan tahun atau ratusan tahun agar kualitasnya terjamin. Perilaku menancapkan ranting di atas bekas pohon yang telah ditebang itu mengingatkan anak-anaknya untuk selalu menanam pohon baru sebagai pengganti pohon yang ditebang sehingga kelestarian lingkungan akan terjamin sepanjang masa.Perilaku yang sangat sederhana yang hingga sekarang masih diterapkan sebagian besar masyarakat di daerah perdesaan Pulau Dewata itu mengandung nilai religiusitas yang multidimensi karena di sana ada tuntunan praktis berkebun (bercocok tanam), tuntunan moral, kasih sayang, dan bermain bagi anakanaknya.Para orang tua di Bali umumnya sejak dini telah menanamkan cara mendidik anak. Seperti sering didengungkan oleh para ahli pendidikan, yakni belajar sambil bekerja. Anak-anak dengan praktik langsung di lapangan akan lebih cepat menangkap dan dijamin bisa diingat seumur hidup.Leluhur orang Bali melukiskan kehidupan yang harmonis dengan menjaga dan melestarikan lingkungan bersih dan hijau guna mewujudkan kehidupan yang bahagia lahir bathin (Moksarham jagadhita). Memelihara kelestarian lingkungan bagi leluhur orang Bali merupakan kewajiban suci sebagai pengamalan nilai ajaran agama. Dengan demikian, upaya mewujudkan Bali yang bersih dan hijau itu didukung konsep kategorisasi hutan yang selama ini dimiliki dan diterapkan masyarakat Bali dalam menjalani kehidupan sehari-hari.Konsep yang menyangkut berbagai hal itu, antara lain Sriwana, yakni kawasan hutan yang harmonis dengan permukiman sekaligus mengatur tentang kawasan hutan yang harmonis dengan tempat suci (Tapawana) dan kawasan hutan yang harus dijaga kesuciannya sehingga tidak diganggu oleh mereka yang tidak bertanggung jawab (Mahawana).Upaya tersebut disertai dengan melakukan penghijauan dan penanaman pohon serta meningkatkan kesadaran dan perilaku masyarakat setempat tentang hidup bersih dan mewujudkan 
lingkungan sekitar masing-masing menjadi hijau.

Jika dipandang dari segi sosial masyarakat bahwa tumpek pengatag itu merupakan media pembelajaran bagi masyarakat untuk belajar saling menghormati dan saling menyayangi, baik sesama manusia maupun terhadap lingkungan.Tumbuh-tumbuhan memiliki rasa kasihan dan rasa peduli kepada yang lainnya. Walaupun dia tidak sekelompok spesiesnya, namun dia mampu memberi makan dan menyediakan kebutuhan binatang dan manusia untuk keperluan sehari-harinya, seperti sayur, buah, kayu, rasa aman tempat berteduh dan sebagainya.Tetapi walaupun demikian,tumbuhtumbuhan tidak pernah memiliki rasa benci, memfitnah, iri hati kepada binatang dan manusia, jika binatang dan manusia ingat memelihara dan melestarikan dirinya. Tetapi jika manusia hanya meminta dan menyakiti tumbuh-tumbuhan dan tidak pernah menanam, memelihara, melestarikan serta tidak pernah peduli padanya, maka tumbuh-tumbuhan pun bisa mencelakakan manusia sehingga terjadi bencana, seperti banjir, tanah longsor, gempa, angin ribut, yang mana semuanya akan membuat manusia dan hewan menjadi celaka dan sengsara.Warisan budaya untuk melestarikan lingkungan, seperti contoh, setiap ada kayu besar di Bali, kebanyakan diisi saput poleng yang disakralkan oleh umat Hindu untuk dijadikan tempat pemujaan yang dilestarikan secara rohani dengan jalan setiap hari menghaturkan sesajen menurut kepercayaan agama Hindu bahwa di sana diyakini ada sesuatu yang bisa membuat kita celaka kalau kita lewat, seperti jin, tonya, banaspatiraja dan sebagainya agar manusia itu tidak diganggu dalam kehidupannya sehingga menjadi jagadhita dalam hidupnya.Tetapi, jika kita pandang dari segi ilmu bahwa pohon-pohon yang besar dapat berfungsi menghatur terjadinya sirkulasi air di mana air laut dipanaskan oleh matahari akan menguap, kemudian dari uap akan berubah menjadi embun, embun di daerah lembab akan menjadi hujan, air hujan ditahan oleh akar-akar pohon kemudian dialirkan perlahan-lahan melalui sungai menuju sumbernya (muaranya) lagi, yaitu laut.Maka, melalui hari raya tumpek uduh ini, manusia pada umumnya dan umat Hindu pada khususnya mulai belajar untuk bisa menanam, memelihara tumbuh-tumbuhan melalui reboisasi atau penghijauan kembali.

Tumpek uduh dipakai objek adalah tumbuh-tumbuhan adalah pedoman bagi manusia pada umumnya dan umat Hindu pada khususnya agar tumbuh dalam pikirannya untuk melestarikan lingkungannya dengan jalan saling menghormati, saling menyayangi, saling memelihara, dan saling membantu serta saling menolong di antara semua insan ciptaan Tuhan.Jika dikaitkan terhadap nilai ekonomi, perayaan tumpek pengatag dijadikan perenungan intelektual masa depan membangkitkan sektor pertanian. Walaupun lahan di perkotaan sudah kebanyakan alih fungsi, perlu adanya tindakan nyata melalui kreativitas dan motivasi membangun pertanian perkotaan, salah satunya adalah memanfaatkan lahan sempit dengan komoditas bernilai ekonomi tinggi.Dengan melestarikan budaya upacara tumpek pengatag, masyarakat menjadi lebih bisa melestarikan lingkungan dengan menanam tumbuh-tumbuhan pada lahan kecil pun. Dengan demikian, secara tidak langsung masyarakat akan memperoleh hasil dari tumbuhan yang ditanam, baik buah, kayu, maupun daun. Yang mana hasil dari tumbuhan tersebut juga dapat memberikan nilai yang tinggi apabila dijual di pasaran.

Tradisi perayaan tumpek pengatag tidaklah keliru jika disepadankan sebagai peringatan Hari Bumi gaya Bali. Tumpek pengatag merupakan momentum untuk merenungi jasa dan budi Ibu Bumi kepada umat manusia.

\subsection{Kearifan Lokal untuk Meningkatkan Mutu Pendidikan Karakter}

Pengembangan dan pembentukan karakter diyakini perlu dan penting untuk dilakukan oleh 
sekolah ataupun masyarakat untuk menjadi pijakan dalam penyelenggaraan pendidikan karakter yang sukses. Tujuan pendidikan karakter pada dasarnya adalah mendorong lahirnya anak-anak yang baik. Tumbuh dan berkembangnya karakter yang baik akan mendorong peserta didik tumbuh dengan kapasitas dan komitmen untuk melakukan berbagai hal yang terbaik dan melakukan segalanya dengan benar serta memiliki tujuan hidup. Masyarakat juga berperan membentuk karakter anak melalui orang tua dan lingkungannya.

Karakter dikembangkan melalui tahap pengetahuan (knowing), pelaksanaan (acting), dan kebiasaan (habit). Karakter tidak terbatas pada pengetahuan saja. Seseorang yang memiliki pengetahuan kebaikan belum tentu mampu bertindak sesuai dengan pengetahuannya, jika tidak terlatih (menjadi kebiasaan) untuk melakukan kebaikan tersebut. Karakter juga menjangkau wilayah emosi dan kebiasaan diri. Dengan demikian diperlukan tiga komponen karakter yang baik (components of good character) yaitu moral knowing (pengetahuan tentang moral), moral feeling atau perasaan (penguatan emosi) tentang moral, dan moral action atau perbuatan bermoral. Hal ini diperlukan agar peserta didik dan atau warga sekolah lain yang terlibat dalam sistem pendidikan tersebut sekaligus dapat memahami, merasakan, menghayati, dan mengamalkan (mengerjakan) nilai-nilai kebajikan (moral).

Kearifan lokal merupakan suatu nilai yang hidup dan dipercaya sebagai sebuah budaya yang dibenarkan dan dihormati masyarakat yang memiliki. Muatan-muatan nilai pada kearifan lokal memiliki kesesuain dengan muatan delapan belas nilai pendidikan karakter. Seperti yang disampaikan pada poin kearifan lokal di atas, maka sangatlah baik jika kearifan lokal ini dijadikan jembatan dan fasilitas untuk menanamkan nilai pendidikan karakter.
Lembaga pendidikan harus mulai merumuskan kearifan lokal di daerahnya masing-masing. Kearifan lokal yang dijadikan pedoman dan budaya bagi masyarakat peserta didik. Nilai-nilai kearifan lokal perlu dirinci untuk menjadi poin-poin tegas agar dapat dicermati dan dicerna dengan mudah oleh peserta didik. Penyelarasan nilai kearifan lokal dan pendidikan karakter akan menciptakan sinkronisasi antara teori dan praktik secara utuh dan sesungguhnya. Peserta didik mendapatkan moral knowing di sekolah dan lingkungan melalui pendidikan karakter dan kearifan lokal di daerahnya masing-masing. Acting dan habbit secara sadar dan tidak sadar akan terealisasi di lapangan. Sebab kearifan lokal yang dijadikan fasilitas untuk penanaman nilai karakter, telah mendapatkan tempat yang baik dan dipercaya oleh peserta didik (masyarakat). Kearifan lokal atau budaya yang diterjemahkan dengan baik dan dipadukan dengan nilai pendidikan karakter akan menciptakan harmonisasi moralitas yang baik pula.

Banyak kearifan lokal yang bisa dijadikan pedoman dan fasilitas untuk mempermudah realisasi pendidikan karakter ini. Tinggal menyesuaikan dengan situasi dan kondisi yang terjadi di masyarakat, serta peka terhadap isuisu yang mengguncang keharmonisan. Permasalahan yang sering muncul adalah pembiaran dan keputusasaan dari berbagai pihak. Membiarkan membiaknya rasa perpecahan, permusuhan, dll. Putus asa melihat sesuatu yang nampaknya tidak bisa diubah. Menyikapi ini yang paling dibutuhkan adalah kepekaan. Peka terhadap masalah dan peka terhadap jalan keuar disekitar kita. Ketika masalah intoleransi muncul kepermukaan maka, kita wajib menggali nilai kearifan lokal yang berkaitan dengan penerimaan terhadap perbedaan. Sebagai contoh penerjemahan nilai moral cerita Dalem Balingkang, atau budaya yang ada di Desa Pegayaman merupakan cerminan toleransi yang baik. 
Upaya sangat perlu dilakukan agar pendidikan karakter benar-benar terealisasi. Upaya yang memiliki media yang baik akan dapat mempermudah membentukn manusia yang utuh. Kearifan lokal yang merupakan warisan yang berupa perjalanan panjang pengalaman dari para pendahulu tidak akan siasia dan tidak akan menjadi cerita belaka, jika benar-benar dihayati,"dibedah", dan dijadikan pedoman hidup bermasyarakat. Kearifan lokal dapat dengan baik untuk diberdayakan sebagai fasilitas dan jembatan untuk peningkatan mutu pendidikan karakter. Sebagai harapan untuk membentuk seorang manusia seutuhnya.

\section{SIMPULAN}

Kearifan lokal adalah nilai-nilai yang akan melekat dengan sangat kuat pada masyarakat karena nilai ini melalui perjalanan waktu yang panjang, sepanjang keberadaan masyarakat tersebut. Kearifan lokal merupakan pedoman hidup bagi masyarakatnya. Kepercayaan dan penghormatan terhadap makna kearifan lokal ini merupakan suatu kesungguhan. Salah satunya tumpek uduh/pengatag, sebagai media juga pengingat agar masyarakat bisa memahami bahwa pendidikan karakter sudah seharusnya diberikan sejak dini. Melihat kultur masyarakat yang sangat menghormati nilai-nilai kearifan lokal, maka kearifan lokal ini merupakan fasilitas dan jembatan baik untuk merealisasikan nilai pendidikan karakter pada peserta didik maupun masyarakat luas. Diperlukan sinkronisasi antara nilai kearifan lokal dan nilai pendidikan karakter. Sehingga tercipta mutu pendidikan karakter yang baik dengan media kearifan lokal.

\section{DAFTAR PUSTAKA}

Albertus, Doni Koesoema. 2007. Pendidikan Karakter: Strategi Mendidik Anak di Zaman Global. Jakarta: PT. Grasindo.

Fajarini,Ulfah. 2014. Peranan Kearifan Lokal dalam Pendidikan Karakter. Jurnal Sosio Didaktika : Vol 1 No 2 Desember 2014.

Pusat Kurikulum. Pengembangan dan Pendidikan Budaya \& Karakter Bangsa: Pedoman Sekolah. 2009:9-10

Rahyono. F.X. 2009. Kearifan Budaya dalam Kata.Jakarta: Wedatama Widyasastra. 